\title{
The construction process of grounded theory in administration
}

\author{
El proceso de construcción de la grounded theory en administración \\ Darlan José Roman $^{\mathrm{a}, *}$, Marilei Osinski ${ }^{\mathrm{b}}$, Rolf Hermann Erdmann ${ }^{\mathrm{b}}$ \\ a University of West of Santa Catarina State, Brazil \\ ${ }^{\mathrm{b}}$ Federal University of Santa Catarina, Brazil
}

Received 12 January 2016; accepted 24 June 2016

Available online 10 May 2017

\begin{abstract}
This study aims to analyze the process of grounded theory, from the report of a research practical experience performed in Southern Brazil. It presents conceptual and structural aspects of grounded theory, focusing is on the description of the research process, from a fieldwork, which was carried out in order to understand the implementation phase of performance improvement programs in organizations. The study presents the research process of grounded theory, highlighting the use of analytical tools and research steps, considering the reality of the administration area. The study analyze the use of grounded theory from a real problem faced by organizations. From the results, it is possible to provide some important tips about the way of conducting the method considering the specificities of the organizational studies.

(C) 2017 Universidad Nacional Autónoma de México, Facultad de Contaduría y Administración. This is an open access article under the CC BY-NC-ND license (http://creativecommons.org/licenses/by-nc-nd/4.0/).
\end{abstract}

JEL classification: M1; M16

Keywords: Qualitative research; Grounded theory; Administration

\section{Resumen}

Este estudio tiene el objetivo de analizar el proceso de conducción de la teoría fundamentada en datos, desde el informe de una experiencia práctica de la investigación llevada a cabo en el sur de Brasil. El estudio presenta los aspectos conceptuales y estructurales de la grounded theory, centrándose en la descripción del proceso de investigación de campo sobre el fenómeno de la implantación de sistemas de mejora del rendimiento

\footnotetext{
* Corresponding author.

E-mail address: darlan.roman@unoesc.edu.br (D.J. Roman).

Peer Review under the responsibility of Universidad Nacional Autónoma de México.
} 
en las organizaciones. El estudio presenta el proceso de investigación de la grounded theory, destacando el uso de herramientas de análisis y pasos de la investigación, teniendo en cuenta la realidad del área de administración. El estudio analiza el uso de la grounded theory abordando un problema contemporáneo que enfrentan las organizaciones.

(C) 2017 Universidad Nacional Autónoma de México, Facultad de Contaduría y Administración. Este es un artículo Open Access bajo la licencia CC BY-NC-ND (http://creativecommons.org/licenses/by-nc-nd/4.0/).

Códigos JEL: M1; M16

Palabras clave: Investigación cualitativa; Grounded theory; Administración

\section{Introduction}

The grounded theory has its origin in the scope of the sociology area and it is being presented as an interesting alternative for the qualitative studies on organizational phenomena. The research in administration is methodologically characterized by the balancing between qualitative and quantitative methods. The studies that follow the qualitative way focus in the use of the case study strategy and, on a smaller scale, in the utilization of action research (Marchi, Dellagnelo, \& Erdmann, 2011; Roman, Marchi, \& Erdmann, 2013). Quantitative methods, as grounded theory, however, have been gaining space in the scope of the discussions in academic disciplines and in the realization of empirical research.

In this sense, the intention of this study is not only presenting the grounded theory as a possibility of qualitative research method in administration, but to go a bit beyond. It means to present a description of an empirical experience about the utilization of the method, highlighting some advantages and constraints, as well as introducing some implications of the method in the research process in administration. In the literature, there are some studies with the similar intention. Pinto and Santos (2012), for example, presented a study that shows results from a fieldwork guided by the grounded theory method. Other papers with similar proposal (Freitas \& Mello, 2013; Halaweh, 2012; Kempster \& Parry, 2011; Martin \& Woodside, 2011; Mccreaddie \& Payne, 2010; Papathanassis \& Knolle, in press; Pinto \& Santos, 2012) can be found in the literature.

Although other studies have been done with the proposal of describing the research process with grounded theory, this paper shows some innovative aspects, like the focus in a contemporary empirical problem in the administration area. It is used the method proposed by Strauss and Corbin (2008), which, because of its characteristics, allows presenting to the reader a detailed guide of the main necessary steps in order to build the grounded theory.

It is also noticed that the concern of a great part of the authors revolves around the discussion on generic and abstract aspects of the grounded theory. In rare moments one finds operational and concrete tips about the difficulties and facilities that researchers may face during the process of building grounded theory. In this way, it is intended to provide more knowledge about the effective use of a research method relatively new in the area and encourage qualitative researchers, especially beginners in the method, to explore the world of grounded theory.

Based on the above considerations, this paper was structured in order to present initially the grounded theory method, highlighting the pioneering authors Barney Glaser and Anselm Strauss (Glaser \& Strauss, 1967), as well as the reasons of the appearance of the method and its objectives. In sequence, it presents the report of an empirical experience that is a result of a doctoral thesis related to the implementation of performance improvement systems in organizations, trying to 
understand why so many initiatives do not achieve their initial goals. Indeed, there are reports in the literature (Bourne, Neely, Mills, \& Platts, 2003; Neely \& Bourne, 2000; Scherer \& Ribeiro, 2013; Trad \& Maximiano, 2009; Waal \& Counet, 2009; Walter \& Tubino, 2013) that show the high degree of failure of the implementations.

The paper also presents a discussion section, in which a comparison with other studies is done. In sequence, it presents some practical recommendations for the grounded theory research process in the administration area. It concludes with the final considerations section.

\section{Grounded theory}

The grounded theory was jointly developed by Glaser and Strauss (1967) as a methodology to develop theory from the data systematically obtained from social research (Büscher, 2007). The process of grounded theory contrasts with the deductive logic commonly used, in which the meaning and knowledge are previously established.

Despite the two authors (Glaser \& Strauss, 1967) have presented some differences in the way of doing research, the contribution of both was equally important. Strauss was graduated at University of Chicago, which has a strong tradition in qualitative research. In turn, Glaser was graduated at Columbia University and his research position was influenced by quantitative methods and an empirical perspective (Strauss \& Corbin, 2008).

In the book The Discovery of Grounded Theory, Glaser and Strauss (1967) search to evince how grounded theory, systematically obtained and analyzed from social research, can be developed. The main point discussed by the authors is that the build of grounded theory is a way of reaching an adequate theory for its eventual use.

The Glaser's line adopts a very positivist position, suggesting the researcher's neutrality, and says that the data, sooner or later, will discover the real condition of a specific context. In a second understanding line, Strauss and Corbin (2008) suggest that the grounded theory needs to be observed from a subjectivist and interpretative view, in which the researcher's work and interpretation are fundamental to the process of building both data and theory (Pinto \& Santos, 2008). This more subjectivist and interpretative position is also found in Charmaz (2009). Based on this interpretation, it is possible to notice that the grounded theory presents similarities with the principles of interpretative paradigm, as presented by Burrell and Morgan (1979).

In the theory that emerges from the data, they reveal the behavior of the individuals in a specific context. It is important to observe what literature says and, in the same way, experiences of similar phenomena during the research process, however, according to Strauss and Corbin (2008, p. 54) "[...] it does not means that literature and experiences will be used as data."

According to Glaser and Strauss (1967) there are more formal theories and theories that can be considered substantive. The first are known as great theories, are less specific and can be applied in a broader field. In another way, substantive theories are concerned with specific problems in a specific context, trying to explain a phenomenon from this context. The substantive theories can be replicated by other studies and, in this way, may incorporate characteristics of formal theory.

The grounded theory can help to prevent the opportunistic use of theories that can present doubt about their real adequacy. The doubtful use of theories in order to explain results can occur when the researcher is not able to generate theory from data and, in this way, will be using a theory that better help in the understanding of the data in a general way (Glaser \& Strauss, 1967).

Generating theory from data means that the most part of hypotheses and concepts not only appear from data, but also are systematically worked according to the data that emerge from the 
empirical research. It involves a research process (Glaser \& Strauss, 1967; Strauss \& Corbin, 2008).

The qualitative analysis performed through grounded theory is characterized by the utilization of a set of procedures based on codification processes and theoretical sampling, which are very useful methodologically in order to study and think about social realities. Grounded theory, according to Strauss and Corbin (2008), offers not only a set of procedures but also an enriching manner of thinking about the social reality.

Thereat, the research that uses grounded theory exceeds the description horizon by working with conceptual ordering, with the creation of categories, properties and dimensions and their relationships. According to Strauss and Corbin (2008, p. 35) theory denotes a set of well-developed categories that are systematically interrelated through declarations of relations in order to form a theoretical structure that explains some relevant phenomena.

According to Strauss and Corbin (2008), although the qualitative research is normally related to induction from specific cases to general, there is also the deduction process as the data are interpreted and conceptualized. Thus, the deduction happens based on the data, but also because of previous experiences and knowledge and of the discussions that emerge during the research.

The study presented hereinafter was built observing the procedures suggested by Strauss and Corbin (2008). The theoretical sampling and codification were procedures adopted. The analytical tool called paradigm was also used in order to integrate categories through their properties and dimensions.

\section{The use of grounded theory: an empirical experience report}

The objective of this research was to investigate why companies face difficulties to conduct change projects that aim to improve the competitiveness pattern. As already mentioned, it is possible to notice in the literature that the degree of failure in the implementation of change projects is very high. The decision of exploring this phenomenon is due to the conclusion that current literature does not present a clear understanding about which the real causes of failure and the actions undertaken by managers during the implementation phase are.

The following report about the build process of grounded theory is based on one author of this paper's research experience. All the process of scheduling and conducting the interviews with managers, data transcription, data analysis and codification was undertaken by the author. During the research process, the researcher had support of senior researchers in the method and, mainly, followed the procedures suggested by Strauss and Corbin (2008).

\section{The theoretical sampling}

The study was developed considering the principles of theoretical sampling, as described in Strauss and Corbin (2008). The theoretical sampling is an essential step in the grounded theory process. It consists in the way taken by the researcher in the search for data to build the theory. The sampling is configured during the research process, in other words, the researcher does not determine previously which will be the sample groups, because the data are the ones that will reveal the way to be followed.

The researcher should develop some sensitive abilities in order to support some decisions, for example, the choice about the best cases considering the emergent data. The process of data collection and analysis, in this sense, is cumulative and presents funnel characteristics, to the 
extent that sample groups are becoming more selective, according to the appearance of evidences of theoretical saturation.

Therefore, the procedures of data collection and analysis were carried out in alternating sequences, and five sample groups were formed until the moment of theoretical saturation. In order to present the companies and managers that composed the theoretical sample letters and numbers were used. It was important to protect the participants' real names. The general aspects of theoretical sample and sample groups are shown in Fig. 1. It is possible to notice the identification of the participants through letters and numbers.

In the first sample group or open sampling, that was the first step of empirical research; six interviews were performed with managers of three companies located in Western Santa Catarina

\begin{tabular}{|c|c|c|c|}
\hline Sample group & Company & Interviewee & Interview \\
\hline \multirow[t]{6}{*}{ First } & A & Production director & A1 \\
\hline & \multirow[t]{2}{*}{$\mathrm{B}$} & Administrative manager & B1 \\
\hline & & Engineering manager & B2 \\
\hline & \multirow[t]{3}{*}{ C } & Production manager & $\mathrm{C} 1$ \\
\hline & & Process engineering & $\mathrm{C} 2$ \\
\hline & & Process analyst & C3 \\
\hline \multirow[t]{7}{*}{ Second } & \multirow[t]{5}{*}{$\mathrm{D}$} & Operational manager & D1 \\
\hline & & Operational coordinator & $\mathrm{D} 2$ \\
\hline & & Project manager & D3 \\
\hline & & Project manager & D4 \\
\hline & & Project manager & D5 \\
\hline & $\mathrm{E}$ & Financial planning manager & $\mathrm{E} 1$ \\
\hline & $\mathrm{F}$ & External consultant & F1 \\
\hline \multirow[t]{5}{*}{ Third } & $\mathrm{G}$ & Production manager & G1 \\
\hline & $\mathrm{H}$ & Operational manager & $\mathrm{H} 1$ \\
\hline & \multirow[t]{2}{*}{ I } & Production manager & 11 \\
\hline & & PPC coordinator & 12 \\
\hline & $\mathrm{J}$ & Executive director & J1 \\
\hline \multirow[t]{5}{*}{ Fourth } & $\mathrm{J}$ & Executive director & J1' \\
\hline & \multirow[t]{2}{*}{$\mathrm{L}$} & General manager & L1 \\
\hline & & Human resources manager & L2 \\
\hline & \multirow[t]{2}{*}{$\mathrm{M}$} & Industrial director & M1 \\
\hline & & Production manager & M2 \\
\hline \multirow[t]{3}{*}{ Fifth } & $\mathrm{A}$ & Production manager & $\mathrm{A} 1^{\prime}$ \\
\hline & \multirow[t]{2}{*}{$\mathrm{C}$} & Process engineering & C2' \\
\hline & & Operational coordinator & C3 \\
\hline
\end{tabular}

Fig. 1. Theoretical sampling. Source: the authors (2015). 
State. In this step, in-depth and non-structured interviews were conducted. The objective and question of the research were used as guide in this initial process. During the interviews, in several moments, the researcher intervened and asked questions as Why?, How?, Who? and What happened?. According to Strauss and Corbin (2008), questions like these ones are important in order to find quality information that will be essential in the moment of definition of categories, properties and dimensions.

In the second phase of the theoretical sampling, seven interviews were performed with managers of two companies located in Great Florianópolis region. The choice of these cases was influenced by the results of data analysis of the first sample group. It was noticed the necessity of exploring a large company and interviewing somebody related to the financial area and also interviewing an external consultant.

The third sample group was formed by four companies located in Great Florianópolis and South regions of Santa Catarina state. The results from the previous sample group helped in the cases selection and in the interviews. It is important to highlight, however, that in some situations the choice of "ideal case" was not possible, because of several reasons, such as difficult access to the company.

In the fourth step of the theoretical sampling, the process of selective sampling got started, with the objective of integrating the categories and identifying the relationships between them from the analysis of properties and dimensions.

The cases that formed the fourth sample group are located in the Great Florianópolis and Vale do Itajaí regions. The researcher decided to return to company $\mathbf{J}$ due to the relevance of the case and the interest of the manager in following the research.

The theoretical saturation of the model started becoming more evident with the interviews performed with the fourth sample group. In this moment, only some aspects, mainly related to the dimensional variations and name of categories, needed to be better clarified.

It is important to notice that is the researcher who realizes that theoretical saturation is happening. The evidences that emerge from interviews only reinforce this perception. In other words, the participants of the research do not say directly that the saturation happened, but they reinforce this perception. The researcher, through sensibility, should gather information and conclude if the research is ready to be finished.

Thus, it was decided to finish the research with a fifth sample group, returning to the first group, in order to do a selective sampling and also performing one of the research validation steps. The initial intention was interviewing all managers that had previously participated, however, for several reasons, this possibility was ruled out.

\section{The data collection and analysis}

In Strauss and Corbin's (2008) approach, the term grounded theory is used in order to refer that the theory was derived from systematically grouped and analyzed through a research process data. The data collection and analysis should constitute an interlaced process with the analysis, conducting to new sampling data (Gray, 2012). The analysis starts as soon as the first interview is finished, and the results conduct to the collection next phase and so on, until the theoretical saturation, in other words, until the moment when data do not indicate relevant things, aside from what is already known (Strauss \& Corbin, 2008).

In the research presented here, the interview was the main way used for data collection. The preference was for in-depth and unstructured interview in the beginning and semi-structured interview during the theoretical sampling. In this way, the flexibility during data collection was 
respected, and conditions for the researcher to explore both sensitive and creativity were offered. It is important to notice that other techniques, such as observation and technical literature, were used on a smaller scale during the building of the model.

In the data analysis, procedures such as microanalysis, open codification, axial codification and selective codification were used (Strauss \& Corbin, 2008). However, the usage of these steps does not necessarily follow a sequence, because in for the most part of research these steps are simultaneous (Schröeder, 2009).

In this case, the data collection process started with the selection of the companies that were part of the first sample group. The selection criteria were based in the research's both objective and question. Basically, the study respected three criteria: (1) the company needs to be experienced in implementation; (2) must have been in the market for at least eighteen years; and (3) be located in Santa Catarina state. Regarding the first criterion, the researcher found three different scenarios: companies that had failure in the implementation; companies that had success in the implementation; and companies that were experiencing the implementation process. Some information about the first sample group are showed in Fig. 2.

The initial contact with the companies that formed the first sample group was made by telephone and e-mail. The contact with the companies was the most difficult point during the realization of the research. In many cases there was no acceptances from managers in participating. In other cases, managers simply did not return the contact. These events are in line with what Strauss and Corbin (2008) have written. Because of this, in several situations it is not possible to investigate the "ideal case".

In the moment of the interview, it is important to start with an informal talk about general aspects related to activities of the company. This point is important and recommended in order to create an enabling environment for the interview. After this informal period, it is relevant to ask if it is possible to start and record the interview.

After the conclusion of the interview, it is important to initiate the transcription process. The transcription of interviews is normally a hard phase and it demands a lot of time and attention. In this study all the interviews were transcribed by the researcher; what is considered important in order to preserve the proximity with data and to encourage both creativity and sensibility.

Whenever possible, the data analysis should be done between the interviews because the analysis results should support the next steps. In the present study this process was followed. Also, the software of qualitative data analysis NVivo was used in order to facilitate handling the data. From coded sections or analysis units, codes were created. Preliminary codes originated categories and subcategories.

\begin{tabular}{|l|l|l|l|l|}
\hline Interview & City & Date & Duration (min.) & Improvement system \\
\hline A1 & Joaçaba & Jan. $15^{\text {th }} 2013$ & 32 & Enviromental management \\
\hline B1 & \multirow{2}{*}{ Luzerna } & Jan. $25^{\text {th }} 2013$ & 28 & Quality management \\
\cline { 4 - 4 } B2 & & Jan. $25^{\text {th }} 2013$ & 38 & \\
\hline C1 & \multirow{2}{*}{ Joaçaba } & Jan. $23^{\text {th }} 2013$ & 34 & Lean production \\
C2 & & Feb. $5^{\text {th }} 2013$ & 32 & \\
& & Feb. $5^{\text {th }} 2013$ & 34 & \\
\hline
\end{tabular}

Fig. 2. First sample group.

Source: the authors (2015). 
Due to its characteristics, NVivo can be considered a software used to create theory, because it aims to support both process and procedures of grounded theory (Lage, 2011). The objective of NVivo is to offer the researcher an agile way to the data analysis process, in order to allow more reliability in the results and support the decision-making process (QSR International, 2012).

NVivo is considered an interesting tool to improve the data analysis process in grounded theory, because it allows the codification of material using several techniques, as codification of paragraphs or codification In Vivo. Similarly, with NVivo, it is easier to explain the connection between data to create categories and the relations between categories and subcategories. The functionalities offered by NVivo are considerable. However, it is important to emphasize that the researcher should be aware that the software is a support tool and the main decisions about the research will be made by the researcher.

Normally, open and axial codification are done in a simultaneous way. Firstly, codes are created through open codification and, after, they are grouped by similarity of meaning, originating the first categories. These seminal categories will support the build of the interview guide that will be used in the next research steps.

In the end of first step, it is possible to notice some needs and orientations, for example, which cases should be used, which questions should be added or removed in the interview guide. It is important to observe what data are indicating in order to avoid building a theory disconnected from the empirical evidences. In Fig. 3, some information about the second sample group is shown.

The third step of data analysis of this study was very hard. Several attempts of scheduling were done without success. So many managers seemed to be upset because of the large number of requests coming from the academic environment. In this sense, one interesting alternative can be trying to contact companies that are known as "open doors" to academicians. Some information about the third step of this study is shown in Fig. 4.

During the study some setbacks appeared, but some events increased the researcher's selfesteem. In several moments the managers congratulated the researcher for the work and declared that the theme was very interesting and was a real problem faced and hard to solve. In other moments, the managers told the researcher they would like to be informed about the progress of the research and its results.

During the codification process and data analysis the researcher developed some memos and diagrams. These analytical tools support the information record and in the research process in a general way. Memos, according to Strauss and Corbin (2008), are written records of analysis that

\begin{tabular}{|c|c|c|c|c|}
\hline Interview & City & Date & Duration (min.) & Improvement system \\
\hline D1 & \multirow[t]{5}{*}{ Palhoça } & Apr. $5^{\text {th }} 2013$ & 32 & \multirow[t]{5}{*}{ NIEPC } \\
\hline D2 & & Apr. $5^{\text {th }} 2013$ & 48 & \\
\hline D3 & & Apr. $5^{\text {th }} 2013$ & 34 & \\
\hline D4 & & Apr. $5^{\text {th }} 2013$ & 41 & \\
\hline D5 & & Apr. $5^{\text {th }} 2013$ & 32 & \\
\hline E1 & Florianópolis & May $17^{\text {th }} 2013$ & 44 & Quality management \\
\hline $\mathrm{F} 1$ & Florianópolis & May $27^{\text {th }} 2013$ & 72 & Quality national award \\
\hline
\end{tabular}

Fig. 3. Second sample group. Source: the authors (2015). 


\begin{tabular}{|l|l|l|l|l|}
\hline Interview & City & Date & Duration (min.) & Improvement system \\
\hline G1 & São José & June $26^{\text {th }} 2013$ & 76 & Lean production \\
\hline H1 & Criciúma & July $4^{\text {th }} 2013$ & Via chat & ISO 15463; 13006 \\
\hline I1 & São José & July $10^{\text {th }} 2013$ & 34 & $\begin{array}{l}\text { Lean production } \\
\text { Quality management }\end{array}$ \\
\cline { 4 - 5 } I2 & July $10^{\text {th }} 2013$ & 32 & Balanced scorecard \\
\hline J1 & $\begin{array}{l}\text { Santo Amaro } \\
\text { da Imperatriz }\end{array}$ & July $18^{\text {th }} 2013$ & 68 & \\
\hline
\end{tabular}

Fig. 4. Third sample group.

Source: the authors (2015).

can vary in type and format. Memos can be like codification notes, theoretical notes or operational notes. In this research, the memos were developed and stored in NVivo Software.

In the fourth step of data collection and analysis three companies that have a successful history in the market were selected. The interview guide used at this moment presented the theoretical model with its categories, properties and dimensions. It is important to highlight that the model was presented in the final part of the interviews, in order to avoid possible influences. The interviews were addressed to some model aspects that needed analytical deepening, for example, some properties, dimensions and names of categories. Some information about the fourth research step is shown in Fig. 5.

After the data analysis of the fourth research step, some modification was done in order to adjust names of categories, properties and dimensions. At this moment, the researcher started the rereading of all interviews, in order to validate the theoretical model that had just been built. The rereading of interviews constitutes one step of research validation. As it will be presented in sequence, there are other ways to make the validation.

The fifth, and last, step of data collection occurred with the main intention of performing another step of validation. It is important to observe that the validation process occurs during all steps of theoretical sampling, however, the final validation is important to ensure that the information presented in the model are reflecting what is specified on the data. As mentioned before, in this study the final validation was made through the rereading of interviews and interviewing again the managers that formed the first sample group. Some information about the fifth research step is shown in Fig. 6.

\begin{tabular}{|c|c|c|c|c|}
\hline Interview & City & Date & Duration (min.) & Improvement system \\
\hline$J 1^{\prime}$ & $\begin{array}{l}\text { Santo Amaro } \\
\text { da Imperatriz }\end{array}$ & Oct. $4^{\text {th }} 2013$ & 56 & Balanced scorecard \\
\hline L1 & \multirow[t]{2}{*}{ Tijucas } & Nov. $5^{\text {th }} 2013$ & 108 & \multirow[t]{2}{*}{ Balanced scorecard } \\
\hline L2 & & Nov. $5^{\text {th }} 2013$ & 49 & \\
\hline M1 & \multirow[t]{2}{*}{ Gaspar } & Nov. $12^{\text {th }} 2013$ & 74 & \multirow[t]{2}{*}{ Lean production } \\
\hline M2 & & Nov. $12^{\text {th }} 2013$ & 36 & \\
\hline
\end{tabular}

Fig. 5. Fourth sample group.

Source: the authors (2015). 


\begin{tabular}{|l|l|l|l|l|}
\hline Interview & City & Date & Duration (min.) & Improvement system \\
\hline A1 & Joaçaba & Jan. $17^{\text {th }} 2013$ & 26 & Environmental management \\
\hline C2 & \multirow{2}{*}{ Joaçaba } & Jan. $17^{\text {th }} 2013$ & 58 & Lean production \\
\cline { 3 - 4 } & & Jan. $21^{\text {st }} 2013$ & 64 & \\
\hline C3 & & & \\
\hline
\end{tabular}

Fig. 6. Fifth sample group.

Source: the authors (2015).

Therefore, the fifth research step was formed by two companies that had participated of the first research step. Thus, at this moment, three validation interviews were performed. There were no significant disagreements regarding the results presented. Only two aspects related to dimensions suffered some adjustments. After this, the theoretical model was considered satisfactory and the research field was completed.

With the theoretical saturation, the substantive theory "A Phase of Change and Learning" emerged. As noted in the substantive reality investigated, the implementation of performance improvement systems can be understood from a perspective of changing and learning. Both structural and behavioral changes are required and, thus, the organization goes through a phase of development and learning, in which it acquires competencies to deal with a dynamic and evolutionary environment. The steps of grounded theory are summarized in Fig. 7.

In Fig. 8 it is illustrated the model that represents the substantive theory "A Phase of Change and Learning". The model is formed by one central category, which is also named as substantive theory, four conditions (Knowing the reality of the company; Planning; Knowledge about how to do; and Top management support), three actions/interactions (Communication; Peoples' involvement; and Control of results), and two consequences (Competitive ability and Cultural change).

Change and learning take place when the company is successful in implementation, but also when the initiatives fail. In case of success, the company will be more developed and in a higher evolutionary level, characterized by the acquisition of skills and competences to deal with change. In case of failure, there was a change to a lower stage, because the company spent resources and

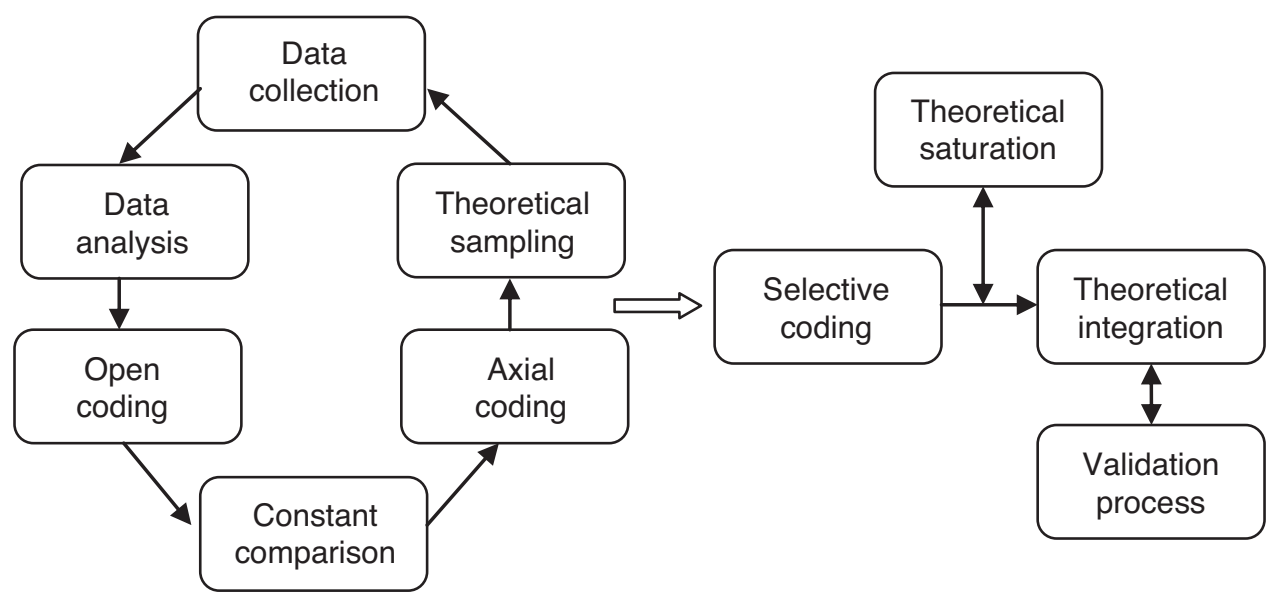

Fig. 7. Steps of grounded theory based on Strauss.

Source: Based on Strauss and Corbin (2008). 


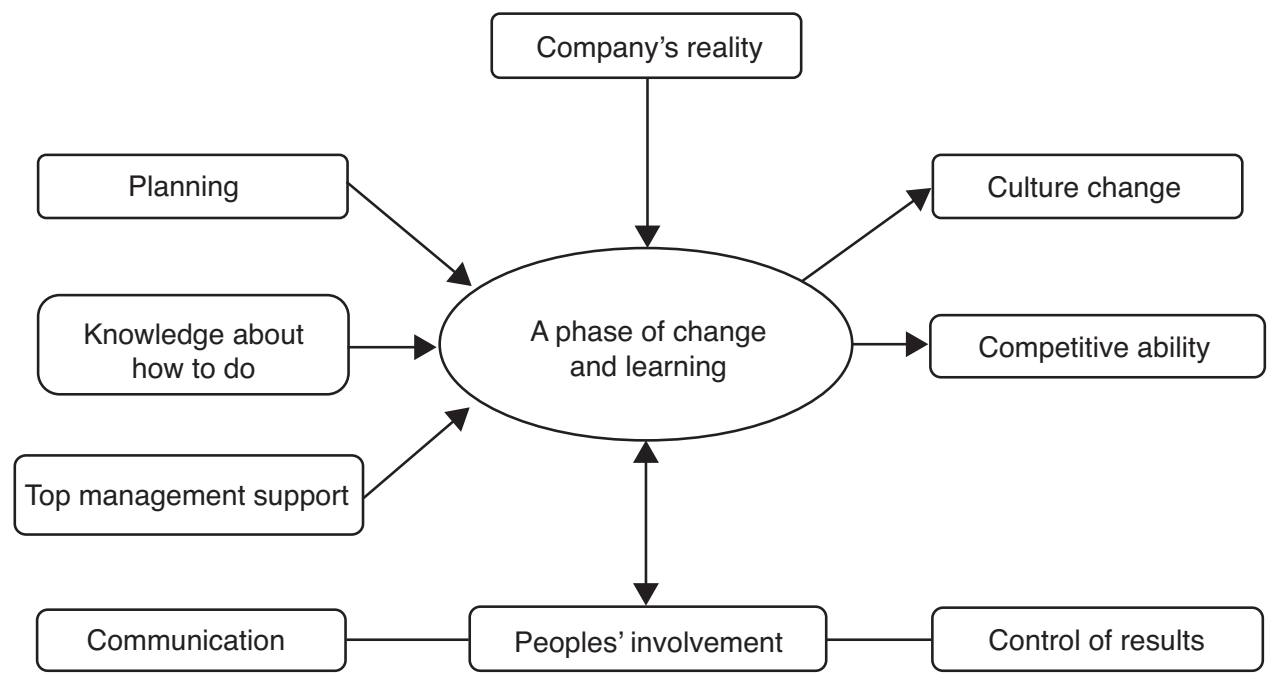

Fig. 8. Substantive theory "A Phase of Change and Learning”. Source: the authors (2015).

returns were not observed. In this case, the resistance for change became stronger and it will hamper new initiatives to implement improvement systems.

Thus, the reality of the company is a condition that creates the situations that conduct to the implementation process. A company that has a good planning, with action plans, indicators and well-defined tasks, will have a favorable condition. Similarly, the degree of knowledge about the model that will be implemented, linked to aspects related to the project management will impact the change program. The support of senior management, in turn, is a condition that can change how the implementation takes place. For example, if there is change in senior management, the support for the implementation can disappear.

The strategy of involving people aims to maintain the support of senior management and motivate people through training and benefits from the change program. Similarly, maintaining communication is a necessary action to preserve a systemic view of the process and to keep people informed about what is happening. The action of control, in turn, aims to preserve what was predicted in the planning and keep company in the right way.

The consequences of the strategies performed are the culture change and competitive ability. According to the efficacy of actions such as involving people, maintaining communication and control, the consequences will be more or less satisfactory. Moreover, the way how conditions are structured will influence the results.

Each category, in its turn, was structured from subcategories, properties and dimensions. In this way, the description of each category was structured in order to enable the reader "enter" the concept and realize how it is grounded. In this way, from the knowledge provided by empirical reality, which is emphasized through the interviews, it was possible to understand how the implementation process occurs. From this comprehension, it is possible to make some reflections about the main aspects that organizations faced on when trying to improve their competitiveness conditions through the implementation of performance improvement systems. 


\section{The theoretical scheme validation}

The validation of the theoretical scheme built from procedures provided by grounded theory should not be understood as a quantitative test. The main concern in this step is to verify if the elements that formed the theory effectively reflect what was said in the interviews, in other words, if the abstractions conceived by the researcher are in accordance with the raw data.

According to Strauss and Corbin (2008), there are several ways to proceed with the validation of the theoretical scheme. One of the ways is returning to the raw data in order to compare to the elements of the scheme. In this validation modality, it is necessary to perform a rigorous comparative analysis in order to verify if the theoretical scheme is able to explain the reality of the cases researched.

Another way of validation mentioned by Strauss and Corbin (2008) is hearing the research participants again in order to present the scheme built, its categories, properties, dimensions and relationships. The participants should see themselves inside the scheme. In a general way, they should be able to identify themselves with the information that are in the scheme.

As mentioned previously, the theoretical scheme built in this study was validated using both ways mentioned by Strauss and Corbin (2008). After the conclusion of the fourth theoretical sampling step, the rereading of all interviews performed was started, in order to conduct a high-level comparative analysis. This is a step that demands a lot of time and attention.

The other validation step of the scheme was made returning to the first cases. Because of some difficulties in scheduling interviews, company B did not participate. In this way, the validation was performed with cases $\mathrm{A}$ and $\mathrm{C}$. The final theoretical scheme was presented and the researcher "told the story" of the research. This validation phase was considered satisfactory. It was noticed that managers were able to see themselves inside the substantive theory. Some considerations were made, mainly, regarding to the dimensions, however, this can be considered normal, since the model is a reduction of reality and it would be impossible to present some aspects in a more detailed way.

\section{Research limitations}

The study undertaken cannot be considered a complete theoretical approach, since the empirical research was focused on a substantive reality. As qualitative research characteristics, studies that use grounded theory do not present generalizable results. The results presented will not necessarily reflect the reality of other contexts.

Related to the data collection process, it is important to emphasize that there were situations in which the "ideal cases" could not be investigated, mainly because of the difficulty to access the companies. Due the fact that the cases are defined according to data, the researcher did not have time to convince managers to participate. The time is a very important factor, and the researcher should deal with it in order to avoid extending the time planned to finish the research.

The use of interview as a main source of data can be considered a limitation, because in some occasions the speech of the interviewee can be in disagreement with the reality. In this particular point, it is important to notice that the researcher behavior may be crucial to obtain reliable data. The researcher should concern about establishing a reliable relation with the interviewee and never influencing on the answers. 


\section{Discussion}

There is consensus among authors who use grounded theory as a method that it is an alternative to empirical positivist methods that examine pre-established relations in order to test theories (Freitas \& Mello, 2013; Kempster \& Parry, 2011; Martin \& Woodside, 2011; Mccreaddie \& Payne, 2010; Papathanassis \& Knolle, in press; Pinto \& Santos, 2012).

In the research undertaken by Pinto and Santos (2012), it is described an experience with grounded theory from a study with customers of electronic products. The authors follow the interpretative way, as proposed by Strauss and Corbin (2008) and Charmaz (2009). In the study, authors draw attention to the difficulty of using the method, mainly because it is out of the traditional way of researching. In this sense, is some moments, the researcher might feel helpless and, furthermore, the method may be criticized by the academic community. This point of view is also shared by Kempster and Parry (2011).

In the study here presented, it was possible to notice some resistance, mainly from researchers of quantitative nature. However, the main difficulty found was the resistance of the managers to accept participating in the research. This point is not mentioned by the current literature, and authors seem to ignore this fact or they have not faced this difficulty. However, the study highlights that the resistance is greater at the beginning of the research.

In the study undertaken by Kempster and Parry (2011) about the use of grounded theory in the area of organizational leadership, it was found that the adequacy of the method to this theme, however, authors emphasize that the method can be target of critics, mainly because it is out of the positivist tradition and, for this reason, does not present statistical validation. About this aspect, it is important to highlight that the codification techniques mentioned by Strauss and Corbin (2008) and presented in this study, have the function of giving more credibility to the building process of substantive theory. Moreover, in grounded theory it is possible to use statistical tools in some situations. Although it is uncommon, this possibility is present in Strauss and Corbin's (2008) approach.

McCreaddie and Payne (2010) describe the area of organizational psychology and present a possibility of use of the grounded theory. The authors conclude that it will be easier to maintain the naturalness of data using what they called discursive grounded theory. In the same line, Papathanassis and Knolle (in press) have demonstrated concern about the naturalness of data. In this case, the authors highlight the use of previous studies, which cannot be used as data.

The concern about the naturalness of emerging data is also exposed by Glaser (1992). This author, in some moments, has criticized Strauss and Corbin's (2008) approach, because of the set of procedures presented. Glaser (1991) understands that it can neutralize the natural process of emerging data. However, as observed in this study, the approach of Strauss and Corbin, if used with good sense, can preserve the naturalness of the process, providing the operationalization of the research. In this line, Martin and Woodside (2011) have explored an interesting way of collecting data through long interviews, in order to explore the meaning of data in a more effective way.

According to Freitas and Mello (2013), researchers should pay attention to their role in the moment of the research process. The authors emphasize that the researchers are susceptible to interfere in the real meaning of data. To Strauss and Corbin (2008), it is important to preserve an equilibrium between both sensibility and objectivity. There are moments when abstraction is required and moments when the researcher should be more objective and decide about which categories will be part of the model, what name they will receive and what their position in the substantive theory will be. 
Martin and Woodside (2011) highlight that one critical point of the grounded theory is that results cannot be generalized, but, on the other hand, the richness of the data collected through this method is essential for a holistic understanding about the investigated phenomenon. The fact that the data are not generalized is not a exclusivity of grounded theory; it is a characteristic of qualitative research.

As discussed in the studies about the use of grounded theory in the administration area, it is noticed some concern from authors relating to general aspects of the method. In rare moments it is possible to find more operational and concrete tips about the difficulties and facilities that the researcher may face during the research process. In this respect, the study here presented show some punctual aspects with the intention of supporting grounded researchers.

\section{Suggestions for researchers in the administration field}

This section aims to present some practical considerations in order to support researchers who use grounded theory as method in their researches in the administration area. The suggestions are presented in topics and are the results of the empirical research experienced by the author in the process of building grounded theory presented in this study.

- Difficulties to access the companies: it is a recurring fact which affects great part of the researchers in the administration area. It is suggested that researchers try to explain to participants about the specificities of the method, highlighting the importance of their opinion to the research. It was found in this study that grounded theory can provide an easier way of convincing managers to participate of academic researches. With the grounded theory, managers feel free to express their opinions.

- Researcher's dedication: the process of building grounded theory is intense and requires a lot of time from the researcher to schedule interviews, handle data and write the report. The required time until reaching theoretical saturation is usually not less than twelve months. It is suggested that the researcher dedicate about eight hours per week to the research.

- Knowledge about interview techniques: the interview, although it is not the only source of data, is the main one, and, in this sense, the researcher needs to be able to take the maximum of meaning from respondents. It is recommended that beginners in grounded theory read books and papers that provide some orientation about how to make in-depth interviews. In this regard, Strauss and Corbin's (2008) book presents interesting tips.

- Time planning: the researcher should plan according to the nature of the research. It is recommended the development of emergency action plans, mainly related to cases selection. It is not always possible to research the "ideal cases" and, in this sense, it is acceptable to focus on less relevant cases and ensure the research conclusion.

- Dealing with existing theories: contrary to what many researchers believe, the grounded theory is not a method that ignores the existent theories. The researcher must have deep knowledge on existing theories that address to the investigated phenomenon. This fact will facilitate the justification of the study and, mainly, in the process of data collection and analysis. The existing theories can be used during the development of the grounded theory (but not as data), for example, in the moment of naming categories.

- Use of analytical tools: in this particular, it is suggested the analytical tools presented by Strauss and Corbin (2008), which are mentioned is this study. It is presented the codification process and the "paradigm" that are used to support the building of the substantive theory. 
Finally, it is recommended to the researcher to pay attention to the several approaches on grounded theory and use the most appropriate approach for the context investigated. In this study, Strauss and Corbin's (2008) approach was considered the most appropriate and provided ways to reach the proposed objective.

\section{Final considerations}

The main objective of this study was to present a description of an empirical experience about the use of grounded theory in the administration area. Thus, some conceptual aspects on grounded theory and the experience report were presented. Some advantages and constraints of the method were highlighted, as well as tips about difficulties and facilities regarding the research's operationalization.

The way how the procedure of data collection and analysis happens is an important characteristic that provides some differentiation to the investigations in relation to other methods. The process of data collection and analysis is systematically performed. Pre-designed theoretical models are not used as data, and the data collection is normally guided by the previous results of the research. The codification process, the analytical tools and the constant validation of the data provide reliability to the results.

The researcher should pay attention to some particular points before starting the research. It is highlighted the resistance from companies to participate of the research, the researchers dedication, the required time to conclude the research, the knowledge about interview techniques and the approach about the existing theories.

It is also highlighted that the method is used essentially to empirical problems, and the results are predominantly built through experiences and perceptions of the participants of the research. In this way, the method here presented provides an empirical knowledge to the science of administration, without, however, neglecting the existing theoretical aspects.

Finally, this study intends to contribute to the process of qualitative research in the administration area. It highlights that the procedures described by Strauss and Corbin (2008) were created from research experiences in sociology and health areas. This study, by the way, uses these procedures from a research experience in the administration area and the suggestions are presented considering the specificities of this area of knowledge.

\section{References}

Bourne, M., Neely, A., Mills, J., \& Platts, K. (2003). Why some performance measurement initiatives fail: Lessons from the change management literature. International Journal of Business Performance Management, 5(2/3), 245-269. Available at: http://www.inderscience.com/dev/search/ index.php?mainAction=search\&action=record\&rec_id=3250\&prevQuery=\&ps=10\&m=or.

Burrell, G., \& Morgan, G. (1979). Sociological paradigms and organizational analysis. London: Heinemann.

Büscher, A. (2007). Negotiating Helpful Action: A substantive theory on the relationship between formal and informal care. (Doctoral Thesis). Tampere: Department of Nursing Science, University of Tampere.

Charmaz, K. (2009). A construção da teoria fundamentada: guia prático para análise qualitativa. Porto Alegre: ARTMED.

Freitas, A. S., \& Mello, R. B. (2013). Uma grounded theory para a ação gerencial no processo de implementação do e-learning nas escolas de negócios do Brasil. BASE - Revista de Administração e Contabilidade da UNISINOS, 10(2), 100-116. Available at: http://www.spell.org.br/documentos/ver/10606

Glaser, B. G. (1992). Basics of grounded theory analysis: Emergence vs. forcing. California: Sociology Press.

Glaser, B. G., \& Strauss, A. L. (1967). The discovery of grounded theory: Strategics for qualitative research. New York: Aldine de Gruyter.

Gray, D. E. (2012). Pesquisa no mundo real (2 ed.). Porto Alegre: Penso. 
Halaweh, M. (2012). Using grounded theory as a method for system requirements analysis. Journal of Information Systems and Technology Management, 9(1), 23-38. http://dx.doi.org/10.4301/S1807-17752012000100002

Kempster, S., \& Parry, K. W. (2011). Grounded theory and leadership research: A critical realist perspective. The Leadership Quarterly, 22(n.i), 106-120. http://dx.doi.org/10.1016/j.leaqua.2010.12.010

Lage, M. C. (2011). Utilização do software NVivo em pesquisa qualitativa: Uma experiência em EaD. ETD Educação Temática Digital, 12(n.i), 198-226. http://dx.doi.org/10.20396/etd.v12imar.1210

Marchi, J. J., Dellagnelo, E. H. L., \& Erdmann, R. H. (2011). Pesquisa qualitativa no campo da administração da produção e operações: Enlaces e oportunidades de aplicação. In Anais do III Encontro de Ensino $e$ Pesquisa em Administração e Contabilidade. João Pessoa: ANPAD. Available at: http://www.anpad.org.br/diversos/ trabalhos/EnEPQ/enepq_2011/ENEPQ29.pdf

Martin, D., \& Woodside, A. G. (2011). Gestalt modeling of international tourism behavior: Applying dimensional qualitative research in constructing grounded theory. Psychology e Marketing, 28(10), 998-1026. http://dx.doi.org/10.1002/mar.20425

Mccreaddie, M., \& Payne, S. (2010). Envolving grounded theory methodology: Towards a discursive approach. International Journal of Nursing Studies, 47(n.i), 781-793. http://dx.doi.org/10.1016/j.ijnurstu.2009.11.006

Neely, A., \& Bourne, M. (2000). Why measurement initiatives fail. Measuring Business Excellence, 4(4), 3-7. http://dx.doi.org/10.1108/13683040010362283

Papathanassis, A., \& Knolle, F. (2011). Exploring the adoption and processing of online holiday reviews: A grounded theory approach. Tourism Management, 32(n.i), 215-224. http://doi.org/10.1016/j.tourman.2009.12.005

Pinto, M. R., \& Santos, L. L. S. (2012). A Grounded Theory como Abordagem Metodológica: Relatos de uma experiência de campo. Organizações e Sociedade, 19(62), 417-436. http://dx.doi.org/10.1590/S1984-92302012000300003

Pinto, M. R., \& Santos, L. S. (2008). Em busca de uma trilha interpretativista para a pesquisa do consumidor: Uma proposta baseada na fenomenologia, na etnografia e na Grounded Theory. RAE-eletrônica, 7(2), 1-20. http://dx.doi.org/10.1590/S1676-56482008000200009

Qsr International (2012). Sobre a QSR International e o NVivo. Available at: http://www.qsrinternational.com/ other-languages_portuguese.aspx

Roman, D. J., Marchi, J. J., \& Erdmann, R. H. (2013). A abordagem qualitativa na pesquisa em Administração da Produção no Brasil. Revista de Gestão, 20(1), 131-144. http://dx.doi.org/10.5700/issn.2177-8736.rege.2013.62026

Scherer, J. O., \& Ribeiro, J. L. D. (2013). Proposição de um modelo para análise dos fatores de risco em projetos de implantação da metodologia lean. Gestão e Produção, 20(3), 537-553. http://dx.doi.org/10.1590/S0104-530X2013000300004

Schröeder, C. S. (2009). Educação a distância e mudança organizacional na Escola de Administração da UFRGS: uma teoria substantiva. (Doctoral Thesis). Porto Alegre: Universidade Federal do Rio Grande do Sul. Available at: http://www.ufrgs.br/gpnavi/artigos/Tese_Christine.pdf

Strauss, A., \& Corbin, J. (2008). Pesquisa qualitativa: Técnicas e procedimentos para o desenvolvimento de teoria fundamentada. (2 ed.). Porto Alegre: Artmed.

Trad, S., \& Maximiano, A. C. A. (2009). Seis sigma: Fatores críticos de sucesso para sua implantação. Revista de Administração Contemporânea, 13(4), 647-662. http://dx.doi.org/10.1590/S1415-65552009000400008

Waal, A. A., \& Counet, H. (2009). Lessons learned from performance management systems implementations. International Journal of Productivity and Performance Management, 58(4), 367-390. http://dx.doi.org/10.1108/17410400910951026

Walter, O. M. F. C., \& Tubino, D. F. (2013). Métodos de avaliação da implantação da manufatura enxuta: uma revisão da literatura e classificação. Gestão e Produção, 20(1), 23-45. http://dx.doi.org/10.1590/S0104-530X2013000100003 